\title{
Strategi Penyusunan Soal Berbasis HOTs pada Pembelajaran Matematika SD
}

\author{
Dhina Cahya Rohim \\ Universitas Muhammadiyah Kudus, Indonesia \\ Email: dhinacahya@umkudus.ac.id
}

\begin{tabular}{l}
\hline Tersedia Online di \\
\hline $\begin{array}{l}\text { http://www.jurnal.unublitar.ac.id/ } \\
\text { index.php/briliant }\end{array}$ \\
\hline Sejarah Artikel \\
\hline Diterima pada 18 Oktober 2019 \\
Disetujui pada 9 November 2019 \\
Dipublikasikan pada 30 \\
November 2019 Hal. 436-446 \\
\hline
\end{tabular}

Kata Kunci:

$\overline{\text { Penyusunan soal, HOTs, }}$ pembelajaran matematika

\section{DOI:}

http://dx.doi.org/10.28926/briliant .v3i4.374

\begin{abstract}
Abstrak: Salah satu perubahan sistem penilaian pendidikan di Indonesia saat ini adalah diterapkannya penilaian berbasis HOTs (Higher Order Thinking Skill). Penerapan penilaian berbasis HOTs ini bertujuan agar proses pembelajaran khususnya matematika dapat mendorong siswa mengembangkan kemampuan berfikir kreatif. Dalam artikel ini mengkaji secara konseptual dengan tujuan memberikan pengetahuan tentang konsep, karakteristik, dan strategi penyusunan soal HOTs kepada para pendidik. Strategi menyusun soal HOTs yaitu (1) melakukan analisis terhadap kompetensi dasar yang akan dibuat soal HOTs, (2) menyusun kisi - kisi soal, (3) menggunakan permasalahan dalam kehidupan sehari - hari yang menarik, (4) menulis butir soal, serta (5) membuat pedoman penilaian dan kunci jawaban.
\end{abstract}

\section{PENDAHULUAN}

Perkembangan ilmu pengetahuan dan teknologi saat ini menuntut manusia untuk memiliki berbagai kemampuan guna menghadapi masa depan diantaranya adalah keterampilan abad 21 yang terdiri dari berfikir kritis, kreatif, inovasi, komunikasi dan kolaborasi (Redhana, 2019). Kurikulum 2013 disusun untuk meningkatkan keterampilan abad 21 menuntut guru agar berperan penting dalam melatih siswa mengembangkan keterampilan berfikir tingkat tinggi (Yuliandini, Hamdu, \& Respati, 2019). Siswa diharapkan tidak hanya mengetahui dan memahami sebuah pengetahuan tetapi juga dapat menganalisis, mengevaluasi bahkan menciptakan sesuatu dari pemanfaatan pengetahuan yang dimiliki.

Untuk memiliki kemampuan tersebut, maka guru dapat melatih siswa dengan memberikan penilaian berupa soal tes yang berbeda dan menuntut siswa lebih kreatif menerapkan ilmu pengetahuan yang dimiliki. Sesuai dengan Undang - Undang Nomor 14 Tahun 2005, guru mempunyai kewajiban merencanakan pembelajaran, melaksanakan proses pembelajaran serta menilai dan mengevaluasi hasil pembelajaran (Wachyudi, Sukestiyarno, \& Waluya, 2015:21). Evaluasi pendidikan merupakan proses menentukan kualitas pendidikan agar dapat mengetahui mutu atau hasilnya (Wulan \& Rusdiana, 2014:2). Instrumen evaluasi jenis tes merupakan teknik yang paling sering digunakan untuk mengevaluasi hasil belajar siswa (Asrul dkk, 2015:42). Terdapat beberapa jenis tes diantaranya 
adalah (1) tes prestasi belajar (achievement test), (2) tes penguasaan (proficiency test), (3) tes bakat (aptitude test), (4) tes diagnostik (diagnostic test) dan (5) tes penempatan (placement test) (Asrul dkk, 2015:42).

Matematika merupakan ilmu yang didasari konsep abstrak sehingga pemberian materi pelajaran ini dapat dilakukan dengan cara mengaitkan materi dengan kehidupan sehari - hari (Dinni, 2018). Hal ini dilakukan supaya siswa mampu menemukan konsep dari pengalaman di lingkungan sekitar. Matematika tidak hanya berorientasi pada penguasaan konsep atau fakta melainkan lebih kepada kemampuan untuk berfikir kreatif mengaplikasikan pengetahuan dasar yang dimilikinya untuk menyelesaikan sebuah permasalahan (Sumaryanta, 2018:500). Permasalahan yang dimaksud tentunya bukan berupa soal yang biasa disajikan tetapi juga termasuk soal atau masalah - masalah yang berbeda dari soal pada umumnya. Kemampuan siswa mengkaji suatu masalah dan mngaitkannya dengan konsep yang telah dimiliki inilah yag disebut dengan kemampuan berfikir tingkat tinggi atau Higher Order Thinking Skill.

Soal berbasis HOTs telah diujikan dalam ujian nasional sejak tahun 2017 dan komposisinya selalu ditambahkaan pada ujian nasional di tahun berikutnya. Namun demikian, saat ini guru belum mengembangkan penilaian dalam bentuk tes yang membuat siswa berlatih berfikir tingkat tinggi (Yuliandini dkk., 2019). Olleh karena itu penelitian ini diharapkan dapat memberikan deskripsi konsep dan strategi menyusun soal berbasis HOTs pada pembelajaran matematika di sekolah dasar khususnya agar bisa digunakan sebagai bahan acuan guru dalam menyusun instrumen penilaian berbasis HOTs.

\section{PEMBAHASAN}

\section{A. Definisi HOTs (Higher Order Thinking Skill)}

Keterampilan berfikir tingkat tinggi diartikan dalam berbagai sudut pandang yang berbeda menurut para ahli. Higher Order Thinking Skill (HOTs) dirumuskan pertama kali oleh penulis dari Dusquance University, yaitu Susan M Brookhart dalam bukunya yang berjudul 'How to Assess Higher-order Thinking Skills in Your Classroom" (Sofyan, 2019:3) dimana dia mendefinisikan bahwa model ini sebagai metode untuk berfikir kritis, transfer pengetahuan dan pemecahan masalah.

Menurut Lewis \& Smith (dalam Hidayati, 2017:147) bahwa: "Higher order thinking occurs when a person takes new information and information stored in memory and interrelates and/ or rearranges and extends this information to achieve a purpose or find possible answers in perplexing situations". Pendapat tersebut menjelaskan bahwa berfikir tingkat tinggi terjadi saat informasi baru diterima dan saling berkaitan dengan informasi sebelumnya atau memperluas informasi yang sudah ada agar dapat merumuskan jawaban dalam situasi tertentu yang membingungkan.

Sedangkan menurut Brookhart (dalam Hidayati, 2017:147) menyatakan bahwa keterampilan berpikir tingkat tinggi diklasifikasikan menjadi 3 kategori yaitu bentuk transfer hasil belajar, berfikir kritis dan memecahkan masalah. Gunawan (dalam Fanani, 2018:60) menjelaskan HOTs atau keterampilan berfikir tingkat tinggi sebagai proses berfikir yang menuntut siswa mengolah infrmasi yang ada dan dapat menghasilkan pengertian dan implikasi baru dengan cara tertentu. 
Dari beberapa pendapat tersebut dapat disimpulkan bahwa HOTs atau keterampilan berfikir tingkat tinggi adalah proses berfikir yang mendalam tentang pengolahan informasi dalam menghadapi dan menyelesaikan masalah yang bersifat kompleks dan melibatkan keterampilan menganalsis, mengevaluasi dan mencipta. Untuk mengukur keterampilan berfikir tingkat tinggi yang merupakan kemampuan yang bukan hanya sekedar mengingat atau merujuk tanpa melakukan analisis dapat digunakan instrument soal berupa soal berbasis HOTs (Ariyana \& Bestary, 2018:11). Dari penjelasan tersebut dapat dilihat bahwa kecapakan berfikir siswa dapat dikembangkan melalui pemberian konsep HOTs yang menantang.

\section{B. Karakteristik HOTS}

Beberapa ahli menerangkan tentang karakteristik HOTs diantaranya Conklin yang menyatakan bahwa karakteristik HOTs yaitu: "characteristics of higher-order thinking skills: higher-order thinking skills encompass both critical thinking and creative thinking" (Fanani, 2018:63). pernyataan tersebut menyatakan bahwa karakteristik keterampilan berpikir tingkat tinggi mencakup pemikiran kritis dan pemikiran kreatif. Kemampuan berfikir tersebut adalah kemampuan dasar yang dapat mendorong seseorang untuk melihat suatu masalah dari berbagai sudut pandang serta mencari alternatif penyelesaian yang berbeda agar dapat menghasilkan produk baru yang memberikan manfaat bagi kelangsungan hidupnya.

Karakteristik soal berbasis HOTs yaitu (1) dapat mengukur keterampilan berfikir tingkat tinggi, (2) menggunakan permasalahaan yang menarik atau permasalahan dalam kehidupan sehari - hari, dan (3) digunakannya jenis soal dengan bentuk yang bermacam - macam (Ariyana \& Bestary, 2018). Hal tersebut dijabarkan dalam uraian berikut ini.

1. Mengukur kemampuan berpikir tingkat tinggi

Kemampuan tersebut termasuk kemampuan pemecahan masalah (Problem solving), berfikir kritis (Critical thinking), kreatif (Creative thinking), kemampuan penentuan putusan (decision making), dan kemampuan berpendapat (Reasoning). Sejalan dengan pemikiran tersebut, Senk dkk (dalam Ernawati, 2016:210) menjelaskan karakteristik HOTs adalah kemampuan penyelesaian masalah yang memiliki banyak kemungkinan solusi dimana belum diajarkan teori terlebih dahulu. Selanjutnya Goodson, dkk (dalam Ernawati, 2016:211) menyatakan bahwa proses berfikir tingkat tinggi berada dalam keadaan yang beragam dan harus mampu mengikutsertakan penerapannya. Berdasarkan pendapat tersebut dapat dimaknai bahwa HOTs adalah kemampuan yang melibatkan berfikir kritis, menganalisis, mengevaluasi, dan tanggap dalam pemecahan masalah walaupun belum ada teori atau konsep yang diajarkan untuk memecahkan masalah tersebut.

2. Menggunakan masalah dalam kehidupan sehari - hari (kontekstual)

Penilaian yang berbasis HOTs merupakan penilaian yang melibatkan situasi dalam kehidupan sehari - hari dan siswa diharap dapat menerapkan pengetahuan atau konsep dasar yang telah diperoleh untuk memecahkan masalah tersebut. Masalah nyata yang disajikan meliputi masalah kesehatan, ekonomi, lingkungan, dana lam semesta serta peran teknologi dalam kehidupan. Definisi tersebut menyangkut keterampilan siswa dalam 
mengkorelasikan, menerapkan serta mengintegrasikan konsep ilmu untuk memecahkan masalah yang berkaitan dengan masalah kehidupan sehari hari. Ciri - ciri penilaian autentik yang berkaitan dengan kehidupan sehari hari menurut yaitu:

a. Siswa mampu mengembangkan sendiri jawaban yang dibuatnya sehingga tidak sekedar memilih seperti opsi pada soal pilihan ganda;

b. Disajikan tugas kompleks yang berkaitan dengan kehidupan sehari - hari;

c. Tugas kompleks tersebut memiiki beberapa alternative penyelesaian atau beberapa alternative jawaban yang tepat untuk dijadikan solusi dari tuga tersebut (Fanani, 2018:65).

3. Digunakannya soal dengan bentuk yang bermacam - macam

Penggunaan soal dengan bentuk beranekaragam ini memiliki tujuan untuk memberi informasi tentang kemampuan siswa sebagai peserta tes secara detail, terperinci dan menyeluruh. Perakuan ini dipandang sangat penting supaya guru dapat melakukan evaluasi sesuai dengan prinsip penilaian yang bersifat objektif. Serta dapat mengukur kemampuan siswa yang sebenarnya. Penilaian yang dilakukan sesuai dengan prinsip yang ada ini dapat memberikan hasil yang valid tentang tolak ukurnya terhadap kemampuan siswa. Menurut Nafiah (2010:10), terdapat beberapa jenis soal yang dapat dipakai dalam penyusunan soal berbasis HOTs yang juga digunakan PISA pada model pengujian yaitu sebagai berikut:

a. Tes Objektif (Pilihan Ganda)

Soal jenis ini merupakan jenis soal yang kalimatnya belum terselesaikan serta untuk dapat melengkapinya dapat dilakukan dengan cara memilih salah satu dari beberapa alternatif jawaban yang tersedia pada setiap butir soal.

b. Pilihan ganda kompleks (benar/salah, atau ya/tidak)

Instrumen jenis ini bertujuan untuk mengetahui tingkat pemahaman siswa pada sebuah permasalahan secara menyeluruh dan adanya keterkaitan antara kalimat yang satu dengan kalimat lainnya. Sama halnya dengan soal objektif biasa, soal HOTs jenis ini juga berisi hal hal yang berkaitan dengan kehidupan sehari - hari. Siswa diminta untuk menentukan benar atau salah dari beberapa kalimat yang disajikan.

c. Isian singkat

Instrument tes jenis ini merupakan jenis soal dimana siswa diminta untuk melengkapi jawaban dengan jalan mengisikan sebuah kata, angka atau simbol tertentu.

d. Uraian singkat

Soal jenis ini menuntuk siswa untuk mengisi pertanyaan dengan jawaban berupa kalimat singkat atau frase yang tepat sesuai dengan permasalahan yang disajikan.

e. Uraian

Soal uraian merupakan soal yang meminta siswa untuk mengisikan jawaban berupa kalimat yang disusun dan dipadukan dengan pendapatnya menggunakan kata - kata yang disusun sendiri. Soal uraian dapat memberikan kebebasan kepada siswa dalam menuliskan jawaban sesuai ide yang diperolehnya. 


\section{Dimensi Level Kognitif}

Dimensi proses kognitif menurut Bloom terdiri dari enam aspek yaitu mengingat, memahami, mengaplikasi, menganalisis, evaluasi dan mengkreasi atau mencipta (Wahyuni, 2017:134). Sudjana menyatakan bahwa aspek pertama dan kedua yaitu mengingat dan memahami disebut keterampilan berfikir tingkat rendah (Prasetya, 2012:108). Sedangkan aspek yang lain disebut kemampuan berfikir tingkat tinggi. Selanjutnya Bloom membedakan dan mengelompokkan tingkatan dimensi level pengetahuan mulai dari yang rendah atau level menghafal, level sedang dan level tinggi yaitu mengkreasi atau mencipta (Prasetya, 2012:108). Dimensi level pengetahuan dibedakan dalam 6 fase yang meliputi (1) mengingat, (2) memahami, (3) mengaplikasi, (4) analisis, (5) evaluasi, dan (6) mencipta (Effendi, 2018:74). Tingkatan proses kognitif ini sering dipakai untuk menentukan tujuan pembelajaran yang dikenal dengan level kognitif $\mathrm{C} 1, \mathrm{C} 2, \mathrm{C} 3$, C4, C5, dan C6.

Dimensi level kognitif tersebut diklasifikasikan menjadi 3 sebagaimana dijelaskan oleh Puspendik (dalam Fanani, 2018:68) bahwa klasifikasi tersebut terdiri dari (1) level 1 yang merupakan level pemahaman dari suatu pengetahuan, (2) level 2 yang merupakan aplikasi dari pengetahuan yang diperoleh, dan (3) level 3 yang merupakan level menalar. Setiap level tersebut dijelaskan sebagai berikut.

1. Dimensi pengetahuan level 1

Dimensi pengetahuan level ini meliputi pengetahuan pada taraf berfikir $\mathrm{C} 1$ (mengingat) dan C2 (memahami). Instrument soal pada level ini bertujuan untuk mengetahui pemahaman siswa terhadap fakta atau konsep. Kata kerja operasional yang biasanya digunakan dalam menyusun soal yaitu menuliskan, menyebutkan, menghitung, mendaftar ddan lain - lain. Jenis soal pada dimensi level 1 ini bukan termasuk soal HOTs.

2. Dimensi pengetahuan level 2

Dimensi pengetahuan level ini merupakan proses penerapan dari fakta atau konsep yang sudah didapat. Level ini meiputi taraf pengetahuan pada aspek C3 (aplikasi). Kata kerja operasional yang banyak digunakan pada level ini yaitu menggunakan, menerapkan, membuktikan dan sebagainya. Namun deminkian, jenis soal pada level ini juga bukan merupakan bentuk soal HOTs.

3. Dimensi pengetahuan level 3

Dimensi pengetahuan pada level ini meliputi proses berfikir pada level C4 (analisis), C5 (evaluasi) dan C6 (mencipta). Pada level ini siswa harus mampu menerapkan pengetahuan, fakta atau konsep yang telah dimilikinya untuk menjawab pertanyaan - pertanyaan yang disajikan. Siswa juga harus memiliki daya nalar dan logika yang cukup tinggi untuk bisa memecahkan masalah - masalah yang berkaitan dengan kehidupan sehari - hari. Oleh karena itu, jenis soal pada dimensi pengetahuan level ini merupakan jenis soal HOTs atau berfikir tingkat tinggi.

Sedangkan Anderson \& Krathwohl (dalam Fanani, 2018:70) mengelompokkan dimensi pengetahuan menjadi 3 kategori yang disajikan dalam tabel sebagai berikut. 
Tabel 1. Klasifikasi Dimensi Pengetahuan

\begin{tabular}{|c|c|}
\hline Taksonomi Bloom & Kategori \\
\hline mengingat & LOTs (Low Order Thinking Skill) \\
\hline memahami & \multirow{2}{*}{$\begin{array}{l}\text { MOTs (Medium Order Thinking } \\
\text { Skil) }\end{array}$} \\
\hline mengaplikasikan & \\
\hline menganalisis & \multirow{3}{*}{$\begin{array}{l}\text { HOTs (Higher Order Thinking } \\
\text { Skill) }\end{array}$} \\
\hline mengevaluasi & \\
\hline Mencipta & \\
\hline
\end{tabular}

Sumber: Anderson \& Krathwohl (dalam Fanani, 2018:70)

Berdasarkan tabel di atas dapat disimpulkan level kognitif menurut taksonomi Bloom terdiri dari 6 tingkatan mulai dari $\mathrm{C} 1$ (mengingat), $\mathrm{C} 2$ (memahami), C3 (mengaplikasi), C4 (menganalisis), C5 (mengevaluasi), dan C6 (mencipta). Masing - masing level tersebut diklasifikasikan menjadi 3 kategori yaitu kemampuan berfikir tingkat rendah yang disebut dengaan LOTs, kemampuan berfikir tingkat sedang atau MOTs dan kemampuan berfikir tingkat tinggi atau HOTs. LOTs terdiri dari dimensi kognitif $\mathrm{C} 1$, sedangkan MOTs terdiri dari dimensi kognitif $\mathrm{C} 2$ dan $\mathrm{C} 3$. Untuk HOTs sendiri terdiri dari dimensi kognitif C4, C5 dan C6.

\section{Strategi Menysusun Soal HOTs}

Langkah menyusun soal berbasis HOTs memiliki langkah yang sama dengan menyusun soal biasanya (Wahidmurni, 2018:11). Perbedaannya ada pada penggunaan rangsangan berupa penyajian masalah dalam kehidupan sehari - hari. Soal berbasis HOTs lebih menuntut siswa untuk befikir tentang bagaimana penerapan dari fakta atau konsep yang telah dikuasai. Sementara untuk soal yang tidak berbasis HOTs lebih condong kepada jenis soal sederhana yang hanya mengukur kemampuan mengingat atau pemahaman siswa terhadap sebuah kosep serta tidak menyajikan masalah kontekstual yang berhubungan dengan kehidupan sehari - hari.

Strategi menyusun soal berbasis HOTs meliputi beberapa langkah yaitu (1) melakukan analisis terhadap kompetensi dasar, (2) membuat kisi - kisi soal, (3) menggunakan masalah yang menyangut kehidupan sehari - hari, (4) menyusun butir soal dan (5) membuat pedoman penskoran (Fanani, 2018:71). Keseluruhan langkah tersebut diuraikan sebagai berikut.

1. Melakukan analisis terhadap Kompetensi Dasar (KD) yang dapat dibuat soal HOts

Soal dalam bentuk apapun dibuat untuk mengukur ketercapaian rumusan kompetensi yang dirumuskan dalam naskah kurikulum suatu mata pelajaran. Oleh karena KD merupakan rumusan kompetensi yang terakhir dalam naskah kurikulum, maka pendidik harus melakukan analisis KD yang akan dibuatkan soal HOTs, dan memastikan bahwa Indikator Pencapaian Kompetensi (IPK) yang dikembangkan telah memperlihatkan bukti telah tercapainya KD tersebut. Para guru dapat mengkaji dan menelaah tentang KD yang dapat disusun menjadi soal HOTs, karena tidak semua KD dapat dibuat menjadi soal HOTs (Widana, 2017:17). Hal tersebut dapat dilaksanakan secara mandiri maupun melalui forum musyawarah guru. 
2. Menyusun kisi-kisi soal

Kisi - kisi merupakan sebuah matriks yang berisi kriteria yang dibutuhkan dalam menyusun butir soal (Kadir, 2015:72). Penyusunan kisi - kisi ini bertujuan untuk memudaahkan para pendidik dalam menuliskan butir soal berbasis HOTs. Selanjutnya dijelaskan bahwa kisi - kisi yang baik harus memiliki kriteria diantaranya (1) mencerminkan isi kurikulum, (2) memiliki komponen isi yang jelas dan mudah dipahami, dan (3) dapat menuliskan butir soal dari setiap indikator yang tersedia (Kadir, 2015:72). Format kisi - kisi soal dibedakan menjadi 2 bagian yaitu bagian identitas dan bagian matriks (Wulan \& Rusdiana, 2014). Bagian matriks dituliskan dalam bentuk kolom sedangkan bagian identitas dituliskan pada bagian atas matrissedangkan bagian identitas meliputi jenjang/sekolah, mata pelajaran, tahun ajaran, alokasi waktu dan jenis soal sementara pada bagian matriks berupa kolom yang minimal terdiri dari KD, Indikator, materi, jenis soal, dan nomor soal (Wulan \& Rusdiana, 2014). Contoh kisi - kisi penulisan soaal disajikan dalam tabel sebagai berikut. Contoh kisi - kisi penulisan soaal disajikan dalam tabel sebagai berikut.

Tabel 2. Contoh Format Kisi - Kisi Soal

\begin{tabular}{|c|c|c|c|c|c|c|}
\hline \multirow{4}{*}{$\begin{array}{l}\text { Satuan pendidikan } \\
\text { Mata pelajaran } \\
\text { Tahun pelajaran }\end{array}$} & \multicolumn{3}{|c|}{ Kisi - Kisi Ulangan Harian Matematika } & \multirow[b]{2}{*}{ : IV } & & \\
\hline & \multirow{2}{*}{\multicolumn{2}{|c|}{$\begin{array}{l}\text { : Sekolah Dasar Nege } \\
\text { : Matematika }\end{array}$}} & Kelas & & & \\
\hline & & & Waktu & \multirow{2}{*}{\multicolumn{2}{|c|}{$\begin{array}{l}: 30 \text { Menit } \\
\text {.Uraian }\end{array}$}} & \\
\hline & \multicolumn{2}{|c|}{$\begin{array}{l}\text { : Matematika } \\
: 2019 / 2020\end{array}$} & Jenis Soal & & & \\
\hline \multirow[t]{2}{*}{ KD } & Indikator & Materi & Indikator Soal & & & \\
\hline & Pencapaian & Pokok & & $\begin{array}{l}\text { Jenis } \\
\text { Soal }\end{array}$ & $\begin{array}{l}\text { Level } \\
\text { Kognitif }\end{array}$ & $\begin{array}{l}\text { Nomor } \\
\text { Soal }\end{array}$ \\
\hline \multirow{17}{*}{$\begin{array}{l}3.9 . \\
\text { Menjelaskan } \\
\text { dan } \\
\text { menentukan } \\
\text { keliling dan } \\
\text { luas persegi, } \\
\text { persegipanjang, } \\
\text { dan segitiga } \\
\text { serta hubungan } \\
\text { pangkat dua } \\
\text { dengan akar } \\
\text { pangkat dua }\end{array}$} & 3.9 .1 & Bangun & Disaiikan & & & \\
\hline & Menganalisis & Datar & sebuah lapangan & & & \\
\hline & penggunaan & & berbentuk & & & \\
\hline & konsep keliling & & persegi, siswa & & & \\
\hline & persegi pada & & diminta & & & \\
\hline & pemecahan & & menyimpulkan & Uraian & $\mathrm{C} 4$ & 1 \\
\hline & masalah & & jarak yang & & & \\
\hline & kehidupan sehari & & ditempuh untuk & & & \\
\hline & & & mengelilingi & & & \\
\hline & 3.9.2. & Bangun & Disajikan dua & & & \\
\hline & Menentukan luas & Datar & buah benda & & & \\
\hline & persegi dengan & & berbentuk & & & \\
\hline & menggunakan & & persegi, siswa & Uraian & $\mathrm{C} 5$ & 2 \\
\hline & konsep luas & & diminta & & & \\
\hline & persegi dalam & & membandingkan & & & \\
\hline & menyelesaikan & & luas daerah & & & \\
\hline & masalah & & keduanya & & & \\
\hline
\end{tabular}


3. Menggunakan permasalahan yang menarik atau menyangkut kehidupan sehari - hari

Permasalahan yang disajikan berupa permasalahan pada kehidupan sehari hari yang menarik dan dapat memotivasi siswa untuk membaca lebih detail soal tersebut. Guru dapat menggunakan lingkungan sekolah atau lingkungan setempat sebagai stimulus kontekstual agar mampu menarik minat siswa dalam menyelesaikan permasalahan.

4. Menulis butir soal

Naskah soal dapat ditulis dalam bentuk pilihan ganda atau uraian sesuai dengan kebutuhan guru dimana penulisan harus disesuaikan dengan aturan penulisan soal HOTs. Jumlah butir dan bentuk soal disesuaikan dengan kisi kisi yang sudah disusun. Aturan menyusun soal HOTS ini secara umum sama dengan menyusun soal - soal pada umunya, yang membedakan adalah aspek materi serta penggunaan kata kerja operasional yang harus disesuaikan dengan kata kerja pada level kognitif C4, C5, dan C6. Butir soal yang sudah tersusun dituliskan dalam sebuah kartu soal. Salah satu contoh format kartu soal disajikan dalam tabel sebagai berikut.

Tabel 3. Contoh Kartu Soal

\begin{tabular}{|c|c|}
\hline \multicolumn{2}{|c|}{$\begin{array}{l}\text { Kartu Soal Nomor } 1 \\
\text { Mapel : Matematika } \\
\text { Kelas : IV } \\
\text { Semester }: 2\end{array}$} \\
\hline Kompetensi Daasar & $\begin{array}{l}\text { 3.9. Menjelaskan dan menentukan keliling dan } \\
\text { luas persegi, persegipanjang, dan segitiga serta } \\
\text { hubungan pangkat dua dengan akar pangkat dua }\end{array}$ \\
\hline Kompetensi Daasar & Bangun Datar \\
\hline Indikator Soal & $\begin{array}{l}\text { Disajikan sebuah lapangan berbentuk persegi, } \\
\text { siswa diminta menyimpulkan jarak yang } \\
\text { ditempuh untuk mengelilingi taman sebanyak } n \\
\text { kali }\end{array}$ \\
\hline Level Kognitif & $\mathrm{C} 4$ \\
\hline
\end{tabular}

Soal:

1. Alin berlari berputar mengelilingi lapangan berbentuk persegi yang memiliki ukuran panjang panjang sisi $95 \mathrm{~m}$. Berapa jarak yang akan ditempuh Alin jika dia akan mengelilingi lapangan sebanyak 3 kali putaran?

5. Membuat pedoman penilaian dan kunci jawaban

Butir soal yang telah ditulis oleh guru sebaiknya dilengkapi dengan kunci jaaban dan pedoman penilaian (Widana, 2017:17). Pembuatan pedoman penilaian digunakan untuk mengukur hasil pekerjaan dari bentuk soal uraian, sedangkan untuk menilai hasil pekerjaan dari soal yang berbentuk pilihan ganda, pilihan ganda kompleks atau uraian singkat maka perlu dibuatkan sebuah kunci jawabaan. Contoh format tabel kunci jawaban dan pedoman penilaian disajikan dalam table sebagai berikut. 
Tabel 4. Contoh Pedoman Penilaian dan Kunci Jawaban

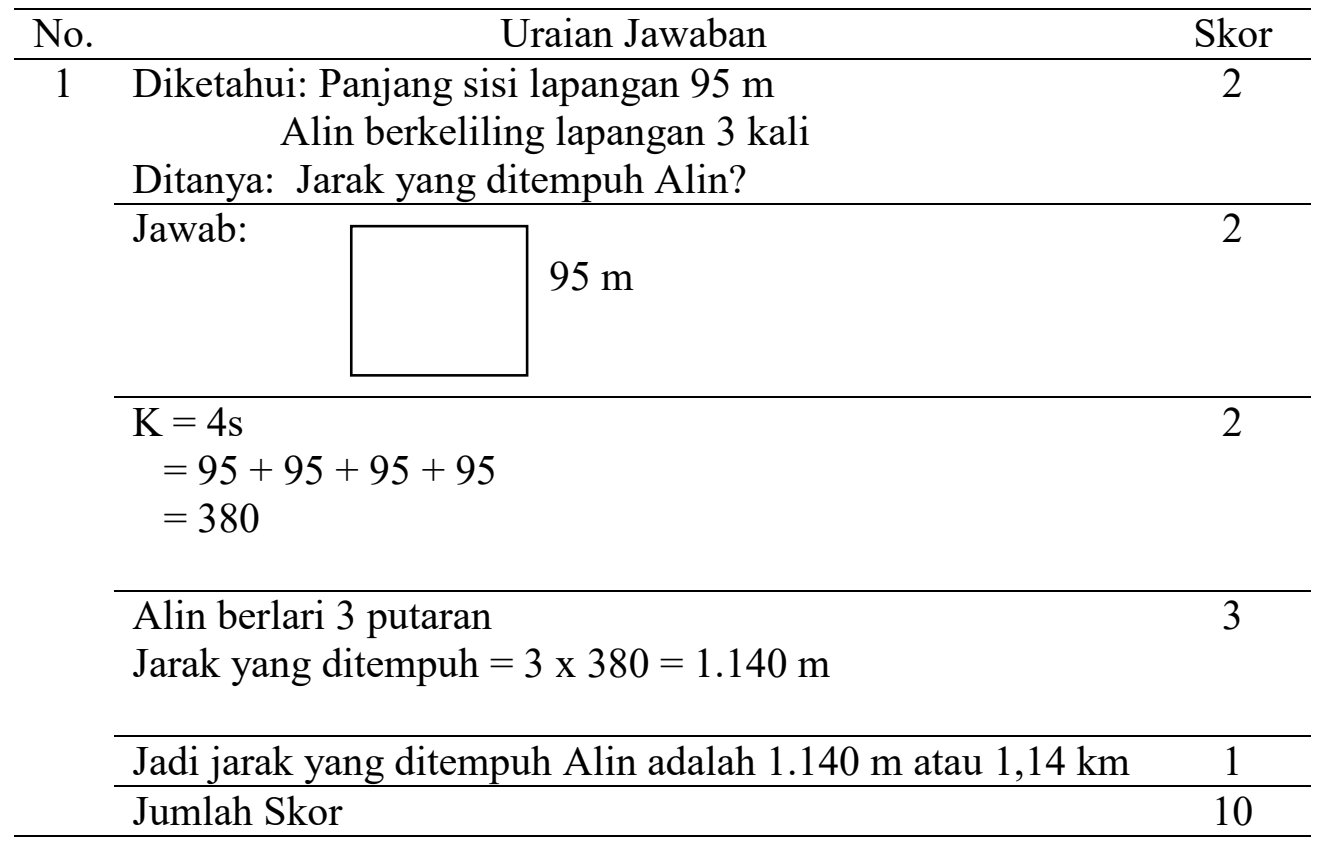

\section{KESIMPULAN}

Dari uraian pada pembahasan dapat disimpulkan bahwa HOTs merupakan proses berfikir yang mendalam tentang pengolahan informasi dalam melengkapi dan menyelesaikan masalah yang bersifat kompleks. Dimensi pengetahuan pada soal HOTs meliputi proses berfikir pada level C4 (analisis), C5 (evaluasi), dan C6 (mencipta). Karakteristik soal berbasis HOTs yatu (1) mengukur kemampuan berfikir tingkat tinggi, (2) menggunakan masalah dalam kehidupan sehari - hari, dan (3) menggunakan jenis soal beragam. Strategi menyusun soal HOTs terdiri dari beberapa langkah yaitu (1) melakukan analisis terhadap kompetensi dasar yang akan dibuat soal HOTs, (2) menyusun kisi - kisi soal, (3) menggunakan permasalahan dalam kehidupan sehari - hari yang menarik, (4) menulis butir soal, serta (5) membuat pedoman penilaian dan kunci jawaban.

\section{SARAN}

Guru sebaiknya melaksanaan penilaiaan dengan jenis soal berbasis HOTs terutama pada pembelajaran matematika di jenjang sekolah dasar. Hal ini bertujuan agar dapat menumbuhkan motivasi belajar siswa karena menuntut siswa untuk mampu menggabungkan konsep yang dimiliki dengan permasalahan yang disajikan dalam soal yang biasanya berupa permasalahan dalam kehidupan sehari - hari. Dengan demikian pembelajaran dapat memberikan kesan yang lebih menarik bagi siswa. Selain itu penggunaan soal berbasis HOTs ini juga dapat melatih siswa untuk berfikir kritis dan kreatif. Guru sebagai kunci pelaksana pembelajaran juga harus senantiasa meningkatkan pemahaman tentang konsep HOTs, sehingga pelaksanaannya dapat berlangsung baik dan memberikan hasil yang maksimal. 


\section{DAFTAR RUJUKAN}

Ariyana, Y., \& Bestary, R. (2018). Buku Pegangan Pembelajaran Berorientasi pada Keterampilan Berpikir Tingkat Tinggi. Direktorat Jenderal Guru dan Tenaga Kependidikan Kementerian Pendidikan dan Kebudayaan Hak.

Asrul, Ananda, R., \& Rosnita. (2015). Evaluasi Pembajalaran. In Citapustaka Media. Bandung: Citapustaka Media.

Dinni, H. N. (2018). HOTS ( High Order Thinking Skills ) dan Kaitannya dengan Kemampuan Literasi Matematika. Prisma, 1, 170-176.

Effendi, R. (2015). Konsep Revisi Taksonomi Bloom Dan Implementasinya Pada Pelajaran Matematika SMP. Jurnal Ilmiah Pendidikan Matematika Volume, 2(1), 72-78.

Ernawati. (2016). Pengembangan perangkat pembelajaran matematika berbasis open-ended approach untuk mengembangkan HOTS siswa SMA. Jurnal Riset Pendidikan Matematika, 3(2), 209. https://doi.org/10.21831/jrpm.v3i2.10632

Fanani, M. Z. (2018). Strategi Pengembangan Soal Higher Order Thinking Skills (HOTS) Dalam Kurikulum 2013. Edudeena, 2(1), 57-76. https://doi.org/10.30762/ed.v2i1.582

Hidayati, A. U. (2017). Melatih Keterampilan Berpikir Tingkat Tinggi Dalam Pembelajaran Matematika Pada Siswa Sekolah Dasar. TERAMPIL Jurnal Pendidikan Dan Pembelajaran Dasar, 4(20), 143-156.

Kadir, A. (2015). Menyusun Dan Menganalisis Tes Hasil Belajar. Al-Ta'dib, 8(2), $70-81$.

Prasetya, T. I. (2012). Meningkatkan Keterampilan Menyusun Instrumen Hasil Belajar Berbasis Modul Interaktif Bagi Guru-Guru IPA SMP N Kota Magelang. JERE(Journal Of Education Research and Evaluation), 1(2), 106-112.

Redhana, I. W. (2019). Mengembangkan Keterampilan Abad Ke-21 Dalam Pembelajaran Kimia. Jurnal Inovasi Pendidikan Kimia, 13(1).

Sofyan, F. A. (2019). Implementasi Hots Pada Kurikulum 2013. Inventa, 3(1), 19. https://doi.org/10.36456/inventa.3.1.a1803

Sumaryanta. (2018). Penilaian HOTS dalam Pembelajaran Matematika. Indonesian Digital Journal of Mathematics and Education, 8(8), 500-509. https://doi.org/10.31227/osf.io/zypex

Wachyudi, B., Sukestiyarno, \& Waluya, B. (2015). Pengembangan Instrumen Penilaian Unjuk Kerja Pada Pembelajaran Dengan Model Problem Solving Berbasis Tik. Journal of Educational Research and Evaluation, 4(1), 20-27.

Wahidmurni. (2018). Pengembangan Penilaian Untuk Mengukur Kemampuan Berpikir Tingkat Tinggi (Higher Order Thinking Skills/HOTS). Kegiatan Workshop Pengembangan Penilaian Kurikulum 13 Bagi Guru-Guru Madrasah Aliyah Negeri Batu, 1-19.

Wahyuni, S. (2017). Development Test System Based on Linear Equations Two Variable Revised Taxonomy Bloom To Measure High Order Thinking Skills At Student Class Viii Smpn Sungguminasa Gowa. Jurnal Daya Matematis, 5(1), 129. https://doi.org/10.26858/jds.v5i1.3035

Widana, I. W. (2017). Penyusunan Soal Higher Order Thinking Skill (HOTS). https://doi.org/10.1017/CBO9781107415324.004

Wulan, E. R., \& Rusdiana. (2014). Evaluasi Pembelajaran Dengan Pendekatan 
Kurikulum 2013. In Pustaka Setia Bandung. Bandung: Puustaka Setia.

Yuliandini, N., Hamdu, G., \& Respati, R. (2019). Pengembangan Soal Tes Berbasis Higher Order Thinking Skill (HOTS) Taksonomi Bloom Revisi di Sekolah Dasar. PEDADIDAKTIKA: Jurnal Ilmiah Pendidikan Guru Sekolah Dasar, 6(1), 37-46. 